\title{
Military symbology and schemes of battalion task force in selected tactical activities (Learning tool) ${ }^{1}$
}

\author{
Marek PANÁK ${ }^{2}$, Jiří ČERNÝ ${ }^{3}$
}

\begin{abstract}
This paper deals with the use of military symbology in accordance with the current standard of the North Atlantic Treaty Organization (NATO) APP-6C from 2012. It analyses the current state of the topic, especially the available resources dedicated to military symbology and schemes of tactical activities of units. The paper defines the procedures and principles in creating tactical symbols and principles for their use in tactical situations. One of the annexes of is an overview of the most common tactical symbols, which provides a standardized, structured set of graphic symbols identifying the most common units, equipment, lines, areas and maneuvers with respect to the current state of the Army of the Czech Republic. This examination also provides the user, through the presentation of MS Office, a comprehensive overview of tactical symbols, as well as short instructions for their use. These symbols can also be removed from the presentation and can be used by the user as the necessary basis for creating one's own diagrams of tactical situations. The next part of this thesis deals with the design of new variants of schemes selected for use in tactical operations of a battalion task force. This schema set is available to the user as well in a presentation of MS Office. Individual schemes are drawn to ensure the required clarity and so this presentation can be used for teaching and by students. This work is a learning tool which can be used by students of The University of Defense especially in subjects like Tactics of Units and Tactics of Formations and, other fields of study as well as in military practices of the units of the Army of the Czech Republic (ACR).

Keywords: Military symbology, schemes, battalion task force, schema set, principles in creating tactical symbols, use of tactical symbols, NATO joint symbology, APP-6C, learning tool.
\end{abstract}

\section{Introduction}

The basic purpose of this paper is to highlight the importance of the knowledge of creation and use of military symbology in the current operating environment.

It is not intended to provide an exhaustive treatise on the issue of military symbology. The aim is primarily to acquaint the reader with the issue of military symbology under a general framework and with available documents dealing with military symbology.

1 This article is the written form of the presentation that was shown on the Central European Forum on Higher Military Education (CEFME) International Young Scientists Conference on December 2013, NUPS, Budapest

2 Sergeant BSc

3 Lieutenant Colonel, engineer, Ph.D. 
The most important part of this work is to create a file of the most common site of military symbols, which will serve both for teaching, as well as a database usable when creating custom schemas of tactical situations. The other part is an album of schemas of battalion task forces in selected tactical activities.

The work itself and its annexes should serve students and teachers as support for teaching at the University of Defense and also as an aid for the improvement of individual training in the ACR.

\section{Definition of basic terminology}

Interoperability is the ability to act in a coordinated way, to effectively and efficiently achieve Allied tactical, operational and strategic objectives. [3]

Unit is a military element whose structure provides for the responsibility of the parent folder. [1]

Maneuver is the evolution of the troops on the battlefield with the use of movement in conjunction with fire or firepower to achieve the advantages over the enemy in order to meet the stated purpose. [1]

Maneuver defense is a way of keeping the defense consisting of a combination of active offensive operations for troops with a temporary obstruction prepared status (favorable lines). [1]

Multinational operation is an operation carried out by the forces of two or more cooperating States. [1]

The defense is a basic, but not the decisive nature of the struggle led, in order to repel or thwart the attack of the enemy in a specified area and time, inflicting losses, maintain important premises, preserve strength and resources, and thus create the conditions for its own activity. [1]

Operation represents the military activity or the implementation of the military strategic, tactical, training, administrative task or the provision of assistance, the process of warfare, including movement, supply, attack, defense, and maneuver, which are necessary for the achievement of the objectives of any battle or campaign. [1]

Operating procedures are detailed methods, with the help of which the headquarters and units perform their operational tasks. [3]

Operating environment consists of a summary of the conditions, circumstances and influences that have an impact on the use of skills and decision-making. [4]

Positional defense is the kind of defense that most defense forces deploy in a selected policy area where there will be a decisive battle. It relies mainly on the ability of the forces in the defensive area to keep biased position and checks the terrain between them. Backups are used to increase the depth, to block, or for the renewal of fighting position to counterattack. [1]

Graphical symbol is a graphical shape that is used to display the operational and tactical situations, the stationing of troops, equipment, weapons, and objects on a map, the schema (sketch), screen or projection devices, and is complemented by numerical and text description. [5]

Task force is a temporary grouping of units under the command of the designated Commander, created for the purpose of carrying out certain operations or to meet a specific task. [1] 
Attack is a kind of battle, which is crucial in order to achieve victory. The attack consists in the destruction of the enemy, in his report, the breakdown of the procedure in their own troops into its depth with the use of fire and maneuver. [1]

Attack from direct contact normally starts after the rearrangement or replacement of units in contact with the enemy. Usually requires the implementation of realignment and rotation, including ensuring confidentiality of the activities before the enemy. [1]

Attack after moving from a depth usually takes place from the default, or other area, generally outside the range of the artillery of the enemy. The default space for an attack battalion occupies in the report of the Brigade (the parent). [1]

\section{Analysis of current situation}

The first chapter is devoted to the definition of the basic concepts contained in this work, and describes the current state of the solved problems in the environment of the ACR. In particular, it deals with the analysis of the available literature and its timeliness in comparison with the latest NATO standard APP-6c (Joint Symbology). In addition, this section deals with the analysis of the specific graphical symbols and principles for their use. The last part of the first chapter is an analytical description of the use and nature of graphical symbols.

\section{Analysis of the available literature}

As has already been mentioned above, this section deals with the analysis of the available NATO and national military documents, especially the literature dedicated to the issue of graphical symbols. The basic and fundamental document for the design issue is the Alliance document APP-6 published in May 2011. This publication provides the user with all the military vital information about graphical symbols. In the introduction it describes the dividing of graphical symbols on land, air, maritime (surface, beneath the surface) and the space units. Furthermore, there is a defined division of the graphical symbols that are used to display weapons, material, vehicles and equipment. Graphical symbols show friendly units, units of the enemy, neutral and unknown forces.

After this initial division into individual categories, this Alliance publication also deals with their creation and use, in particular the principle of locating and describing each of the symbols with the appropriate default defined fields. This publication is not trying to create a database of all graphical symbols, as in the case of the previous document APP-6A (1999). There are more displayed individual icons forming the symbol and it is always shown as an example, the description of their location.

The following figure shows an example: Here is the icon depicting the mortar, it also shows the fields in the frame of its own symbol, where you can place this icon, and last but not least there is a specific example of use, in this case the unit towed mortars.

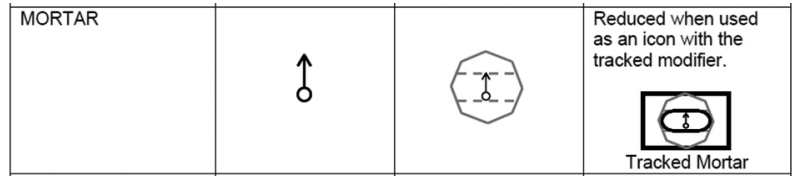

Figure 1. Example of icon and default fields (APP-6C) 
A custom document is very easy to understand, thanks to this structure, and at the same time very versatile and usable. The user does not have to pick a symbol from a prebuilt database, it presents individual icons from which the symbol consists and introduces the principles of their placement to the user.

The publication also describes the symbols for the coordination of the activities of the units, such as: lines and interfaces, maneuvers, command and control, fires ... etc. The last part the document also contains meteorological symbols. The document is currently not available in Czech translation.

Literature, dedicated to the military symbology in the ACR is mainly the publication Pub-53-01-4 Štábní práce v operacích - 3. část of the year 2009, which is based on document $A P P-6 B$, from 2008. This publication also provides instructions on how to form graphical symbols and how to work with them. Symbols are represented, rather, in the form of a database, and as already mentioned, the publication is based on an old document $A P P-6 B$, and therefore some of the symbols are no longer valid.

The last comprehensive document, which deals with the principles of military symbology, is a handbook Situační značky (2005) and is based on the original document APP-6A. This handbook offers a very brief form on the principles of making and use of the symbols. Again, these are rather a small database of specific symbols and a description of the basic principles. As has been already mentioned, the publication is based on the original standard $A P P-6 A$, and thus most symbols do not agree with the current guidelines for creating them.

In the environment of the ACR, there are also other documents devoted to military symbology but these do not address the complex issues, but rather deal with them only marginally depending on the specialization of the publication. These are for example the three publications: Tactics of the Squad (Platoon, Company).

\section{Use and creation of military symbology}

In the current multinational operational environment, the emphasis is placed primarily on the interoperability in the area of command and control. This means accurate and unambiguous representation of an operational (tactical) situation, which is an important decisive factor in the process of command and control in the operation. In the common operating environment it is then absolutely necessary to find a common language that will be easy to understand by all actors in an operating environment. An essential part of this language is a graphical representation of the markup and symbols, which can transmit information faster and more efficiently than a lengthy verbal description. In this, the analysis confirmed opinion is the nature of military symbology existence. As mentioned above, the present document, which deals with the issue of military symbology, is APP-6C. This document is currently used by all members of NATO.

Graphical symbols represent the units, equipment, vehicles and other elements related to activities in the operating environment. The symbol is formed from the frame, the main character (icon), color fill, and other ancillary data and symbols are placed in the appropriate fields.

Using the frame, we define the identification of a unit, or an object that is represented by the symbol. Using the shape of the frame we also divide units on land, air, maritime (surface, beneath the surface) and the space units, equipment, facilities, and activities. The main icon 
is placed in the middle of the brand and represents the image of the unit, equipment, facility, or activity. Some of the icons, for example, technique, or weapons may be used without the frame, these are further defined in the APP-6C. Sectorial icons 1 and 2 are located above and below the main icon in the area, its Octagon, which is used for the layout of the individual icons within frame signs. ${ }^{4}$

Full-frame icons are a special kind of main icon, which go beyond the boundary of the octagon and occupy the entire frame of the symbol. For example, the symbol for recognisance unit. (Figure 2)

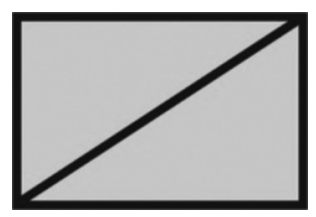

Figure 2.

Recognisance unit (own source)

Additional information is located outside the frame in the appropriate fields. (Figure 3)

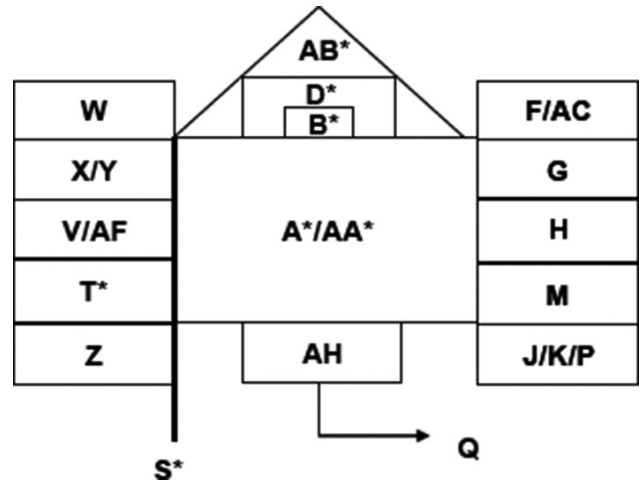

Figure 3. The label field of the symbol (APP-6c)

The symbols indicating the points, lines, areas, and tactical activities is governed by its own rules for label placement and display fields that vary according to the type and purpose of the symbol. As regards the displaying, you can draw the following symbols in either black or white (depending on the background), or color. Color can be used for own forces - blue, red for enemy, green for the obstacles, and yellow for the chemically contaminated areas.

The following illustration shows the fill and border colors that are used for creating graphical symbols. The use of color varies according to the method of view. The 3 number sequence shows the designation of the appropriate color in the RGB-model. (Figure 4)

4 A detailed description of the purpose of each of the icons, including the so-called, Full-frame icons are part of the annex to this work - presentation Tactical symbols. The use of color, display options, and also the detailed description of all label fields is also clarified. 
Marek PANÁK, Jiř́ ČERNÝ: Military symbology and schemes of battalion task force...

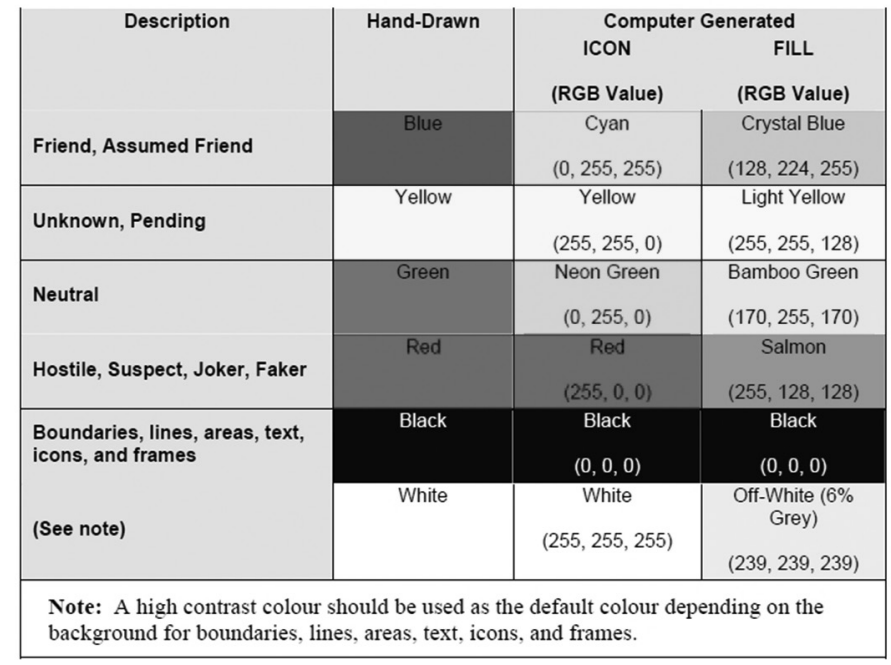

Figure 4. RGB model (APP-6C)

\section{Partial conclusion}

In the part of analysis, dedicated to the available resources on the field of military symbology, this work came to the conclusion that at the present time in the environment of the ACR there is only one current document - APP-6C, which, however, is still not available in Czech translation.

\section{The objectives}

Analyze the current situation of the use of military symbology in the environment of ACR, in regards to the available documents, evaluate the importance of the use of military symbology in the current operating environment, create the database of most used graphical symbols, which will also be a description of the principles for their use,

Create an album of schemes for the battalion task force in the selected tactical activities.

\section{Restrictions}

In this work I restrict, on the basis of interviews with educators from the Faculty of Economics and Management (FEM) (K-110 K-108 and K-107), to the development of the most frequented graphical symbols at the University of Defense.

\section{Used methods of examination}

In this work the following methods have been used to explore:

- Analysis - the basic method that was used in the analysis of available materials in ACR and Alliance materials dedicated to military symbology. 
- Synthesis - through the combination of individual knowledge, which has been obtained by analyzing the available resources in a coherent framework, comes the idea of the content of the work.

- Comparison - this method was used, especially in the parts of the description of the differences between the documents dedicated to the subject.

- Induction - induction was achieved by the transfer of knowledge within the general framework.

- Deduction - method, which helped in the application of general knowledge.

\section{Introduction to military symbology}

As mentioned in the introduction to this work, we can characterize the direction of contemporary operations. We talk about joint multinational operations carried out within the framework of NATO (North Atlantic Treaty Organization) and in the framework of the European Union Battle-groups (EUBG). For the successful conduct of such operations, it is essential to establish a common operational language, as a means of communication, which is used by all interested nations. It is necessary to the established uniform standards for all NATO joint actions. In contemporary operations interoperability plays an important role — that is the required knowledge of common operating procedures and symbolism. This symbolism, also known as military symbology, provides us a universal tool for description of tactical situations and operating tasks without the need for lengthy verbal description. Also there are no more language barriers. Knowledge of tactical symbols is in a contemporary operating environment is absolutely necessary. Consequently, it is necessary to reflect these claims into the preparation of the individual in the ACR, and also into the preparation of students in the University of Defense.

The key objective of this work is creation of the study material that will provide the user an overview of the most commonly used symbols, with regard to the current state of the Army of the Czech Republic. In the next section is an album of schemes of selected tactical activities for battalion task force.

\section{Selected tactical symbols}

As mentioned above, this file provides the user with a form of presentation of MS Office a comprehensive overview of most commonly used symbols, as well as a brief guide to using them. These symbols can be removed from the presentation and can be used by the user as needed, for example for creating custom schemas of tactical situations. Symbols are placed in MS PowerPoint presentation and are also supplemented by the description of fields and represented by a variant of use of the individual symbols.

\section{Album of schemes for battalion task force in selected tactical activities}

Another objective of this work was to create a scheme for battalion task force in the selected tactical activities. This objective constitutes of creation of a PowerPoint presentation, which represents this album of schemes. One of the main requirements, which the author set by the creation of these schemes was their lucidity and clearness. It ensures the fact that the individ- 
ual schemas are drawn according to the steps. In some schemes it was appropriate to split the layers, where each layer represents the terrain, units, maneuvers and obstacles. These layers then, when displayed in a single image, create the schema of tactical activity. (Figure 5 and 6)

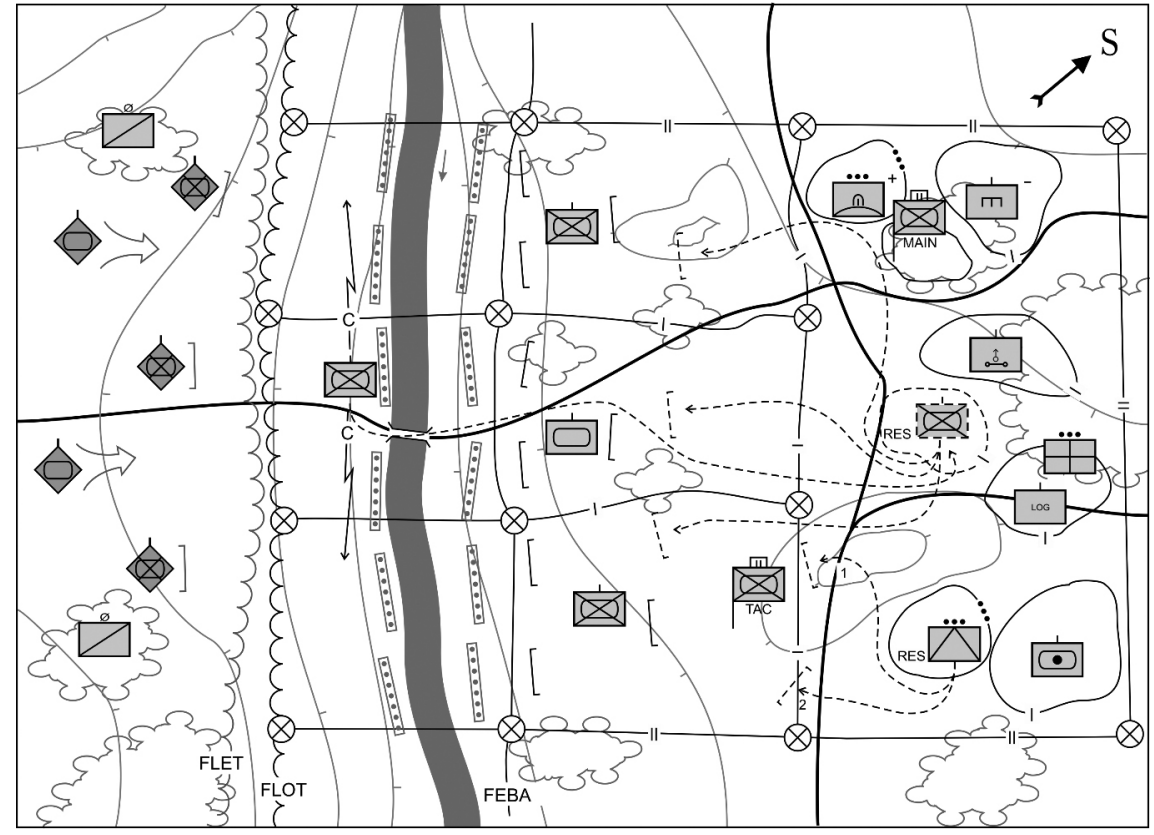

Figure 5. Defense of water obstacle (own source)

The album contains the schemas for the following activities:

- The structure of battalion task force

- Battalion task force in the first echelon of brigade

- The defense of battalion task force

- Fires of battalion task force in defense

- Defense of water obstacle

- Positional defense

- Maneuver defense

- Attack of battalion task force

- Battalion task force in encirclement

- Relieving battalion task force in defense

- Variants of attack of battalion task force

- Attack of battalion task force from the direct contact

- Attack of battalion task force after moving from the depth 


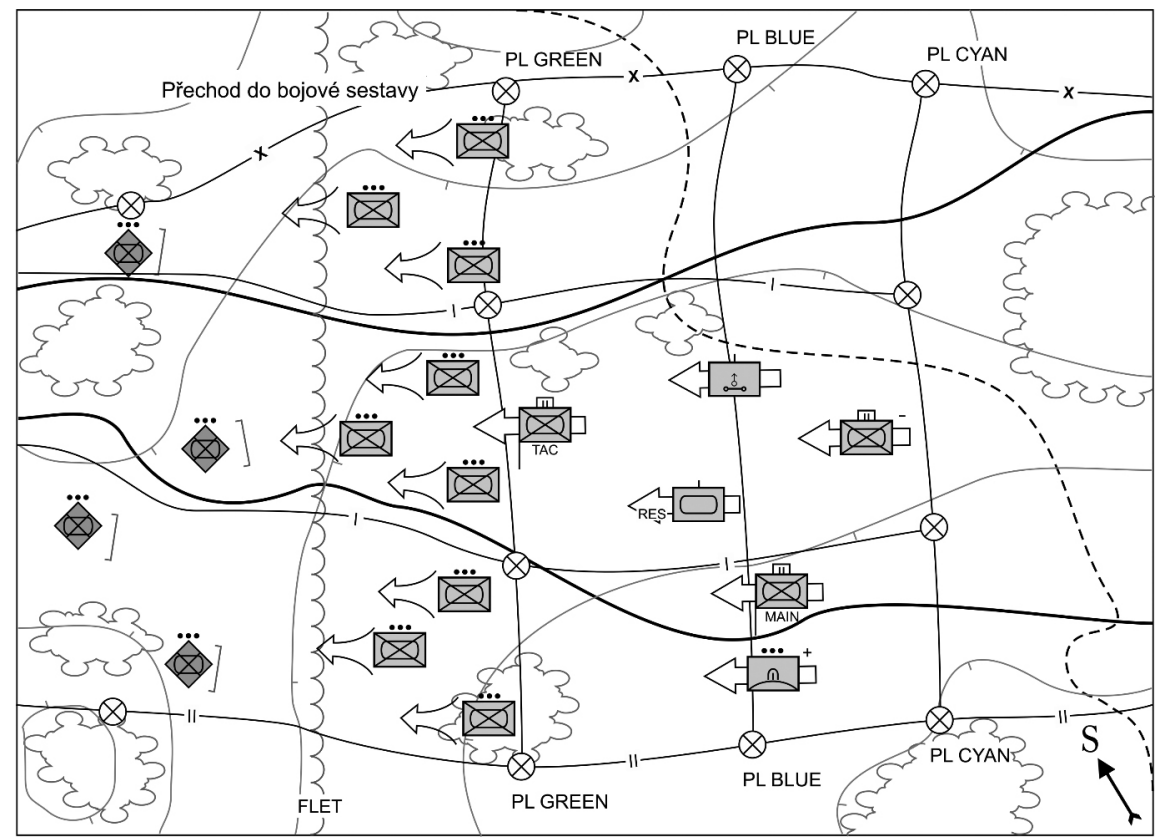

Figure 6. Attack of battalion task force after moving from a depth (own source)

\section{The conclusion}

The analysis found:

In contemporary operations it is necessary to introduce common standards for all joint activities. Knowledge of tactical symbols in a contemporary operating environment is absolutely necessary.

In the contemporary environment of ACR there is only one current document - APP-6C, which, however, is still not available in Czech translation.

On this basis, one can argue that:

It is necessary to incorporate the demands of knowledge of tactical symbols into individual training in ACR, and also in the preparation of students at the University of Defense.

It is necessary to create a handbook dedicated to the issue of military symbology.

This work can be used in military practice as a basis for improvement of training in the area of military symbology. It may also be used by students of the University of Defense for the study of military symbology. This work may also be a teaching tool, available to the teachers of University of Defense, in subjects like tactics of the units and formations.

\section{The final conclusion}

The purpose of this work was to point out the importance of knowledge of military symbology in a contemporary operating environment. The work concludes that in contemporary 
operations it is necessary to introduce common standards for all joint activities. Knowledge of military symbology is absolutely necessary in a contemporary operating environment. In the current ACR environment there is only one document dedicated to military symbology APP-6c, which, however, is still not available in Czech translation, therefore it is necessary to create the handbook dedicated to the issue of military symbology in the Czech language.

\section{References}

[1] Kolektiv autoru: Vojenský výkladový slovník vybraných operačních pojmů. Vyškov: Správa doktrín Ředitelství výcviku a doktrín, 2005.

[2] Kolektiv autoru: Slovník základních pojmů z oblasti vojenského zpravodajství, průzkumu a elektronického boje. Praha: Odbor vojskového průzkumu a elektronického boje MO, 2006.

[3] NATO: APP-6C: Joint Military Symbology. STANAG 2019 edition 6, May 2011.

[4] Pub-100-01-01 (Pozemní operace NATO podle alianční doktríny AJP-3.2)

[5] Situační značky. Vyškov: Správa doktrín ŘeVD, 2005.

[6] Album schémat II (prapor) učební pomůcka. Brno: Vojenská akademie v Brně, Fakulta velitelská a štábní, 1996. 